\title{
Structure of Masera's Septal Olfactory Organ \\ in Cat (Felis silvestris f. catus) - Light Microscopy in Selected Stages of Ontogeny
}

\author{
I. KOCIÁNOVÁ, A. GOROŠOVÁ, F. TICHÝ, P. ČÍŽEK ${ }^{1}$, M. MACHÁLKA ${ }^{2}$ \\ ${ }^{1}$ Department of Anatomy, Histology and Embryology, Faculty of Veterinary Medicine, \\ University of Veterinary and Pharmaceutical Sciences, Brno, Czech Republic \\ ${ }^{2}$ Department of Oral, Jaw and Facial Surgery, Faculty of Medicine, Masaryk University, Brno, \\ Czech Republic
}

Received January 13, 2005

Accepted April 13, 2006

\begin{abstract}
Kociánová I., A. Gorošová, F. Tichý, P. Čížek, M. Machálka: Structure of Masera’s Septal Olfactory Organ in Cat (Felis silvestris f. catus) - Light Microscopy in Selected Stages of Ontogeny. Acta Vet. Brno 2006, 75: 471-475.

The septal organ /SO/ (Masera's organ /MO/) is a chemoreceptor presently considered one of three types of olfactory organs (along with the principal olfactory region and vomeronasal organ). Notwithstanding the septal organ having been first described by Rodolfo Masera in 1943, little is known of the properties of sensory neurons or of its functional significance in chemoreception. Until now the septal organ has been described only in laboratory rodents and some marsupials. This work refers to its existence in the domestic cat (Felis silvestris f. catus).

The septal organ can be identified at the end of embryonic period - 27 or 28 days of ontogenesis in cats (the $6^{\text {th }}$ developmental stage of Štěrba) - coincident with formation of the principal olfactory region in nasal cavity. At 45 days of ontogenesis (the $9^{\text {th }}$ developmental stage of Sterrba), this septal olfactory organ is of circular or oval shape, $120 \mu \mathrm{m}$ in diameter, in ventral part of septum nasi, lying caudally to the opening of ductus incisivus. The structure of the epithelium of septal olfactory organ is clearly distinct from the respiratory epithelium of the nasal cavity. It varies in thickness, cellular composition, as well as free surface appearance, and even lack the typical structure of sensory epithelium, in this developmental period. Nerve bundles and glandular acini are lacking in the lamina propria mucosae of the septal organ and in the adjacent tissues. Glands appear as the single non-luminized cords of epithelia extending from the surface. The adjacent respiratory epithelium contains numerous goblet cells.
\end{abstract}

Septal organ, sensory epithelium, olfactory epithelium, olfactory development

The rat has served as the model for development of the septal organ ( $\mathrm{Gi}$ anetti et al. 1995; Oikawa et al. 2001; Weiler and Farbman 2003). Oikawa et al. (2001) and Gianetti et al. (1995) noted that the rat septal organ initially appears at 15 days gestation and is distinguished by growth associated protein B 50/GAP-43 as a neuronal marker and PGP 9.5. B 50/GAP-43 and PGP 9.5 positive neurons are concentrated in the SO in contrast to surrounding epithelium. During isolation of the SO cells within embryonic and fetal period, continual extension of epithelial surface appears between basic sensory region and SO, while the epithelial cells of this inserted area show reducing immunopositivity of PGP 9.5. At 20 days gestation (neonatus), the isolation process of the $\mathrm{SO}$ is finished, but other increase of glomeruli indicates that differentiation is completed about 7 days after birth (Oikawa, 2001). Gianet ti et al. (1992) suggested the final SO maturation about 15 days post partum.

SO cells are aggregated in dark cell clusters during this period, whereas typical tissue organization, analogous to other parts of olfactory organ appears later. Gianetti et al. $(1992,1995)$ also found that SO cells finish their development after birth. Breipohl et al. (1989) studied development of SO cells by the light and electron microscopy and concluded that the number of olfactory cilia on the epithelium surface increases during the sucking

Address for correspondence:

MVDr. Irena Kociánová

Department of Anatomy, Histology and Embryology, Faculty of Veterinary Medicine

University of Veterinary and Pharmauceutical Sciences

Palackého 1/3, 61242 Brno, Czech Republic

Phone: +420 541562207

E-mail: kocianovai@vfu.cz

http://www.vfu.cz/acta-vet/actavet.htm 
period. This knowledge leads to the conclusion that SO epithelium differentiates more slowly in contrast with the epithelium of the main olfactory region (MOE) as well as vomeronasal organ (VNO). The SO epithelium is more dynamic after birth, unlike the olfactory epithelium which is completely developed and dynamic before birth (Oikaw a et al. 2001). The microstructure of present two types of bipolar sensory neurons depends on the morphology of their apical surface (Taniguchi et al. 1993; Oikawa et al. 1998).

The first type of these epitheliocytes has cilia on its free surface, forms the structures reminding olfactory vesicles and is similar to MOE receptors, whereas the receptors of the second neuron type are equipped by microvilli on their apical surface resembling rather VNO receptors. The first type is dominant, more frequent and regarded to be the main SO receptors, while the second microvillated type is considerably less numerous, nevertheless it is also considered to be a type of olfactory receptors (Taniguchi et al. 1993). Oikawa et al. (1998) found that in comparison with regio olfactoria and the VNO where sensory cells are equipped with both cilia and microvilli, cells of the septal olfactory organ are differentiated as cells with cilia or microvilli, corresponding to the appearance of olfactory epithelium in fishes. They reasoned that on this similarity of olfactory epithelium of fishes and no glands in the SO region of terrestrial animals, the SO rather serves odorant perception in water.

Supporting (sustentacular) cells are more similar to those of the main olfactory region than to sustentacular cells of vomeronasal organ. Oikawa et al. (1998) described two types of supporting cells (SC); the cilliated SC, similar to supporting cells of VNO and the microvilled SC, characterized by concentrically arranged smooth endoplasmic reticulum (SER) and numerous secretory granules in the apical cytoplasm. The aim of our work was to reveal the time and morphology sequence of the development of septal organ in the cat.

\section{Materials and Methods}

Cat embryos and foetuses were measured and weighed immediately after removal of the uterine horns and dissected free of fetal membranes (crown-rump length - CRL). The average number of foetuses in the litter was 3.84. Specimens were matched to developmental stages by Šťrba. Their age was determined by the method of "Staging and ageing" of Štěrba (1995) and on the base of comparable CRL (Ev ans and Sack 1973).

To facilitate light microscopic interpretation, the heads of the individuals from the $5^{\text {th }}-7^{\text {th }}$ development stages were processed and serial, transverse sections were prepared for histological examination. Specimens from later developmental stages were prepared by dividing the skull sagittally and processing only half the head, preparing transverse sections.

For the next treatment samples were taken of mucous from three animals of individual age categories.

Specimens were fixed in $5 \%$ formol for one or two days and then dehydrated in increasing alcohol concentrations $-20 \%, 30 \%, 40 \%, 50 \%, 70 \%, 80 \%, 96 \%$, and $100 \%$, respectively. This prolonged dehydration process minimizes shrinkage artefact, a significant factor embryonic and fetal tissues rich in water. Specimens were then immersed in metylsalicylate (1 h, $2 \mathrm{~h}$, and overnight) and embedded in paraplast. The paraffin blocks were cut with rotary microtome, producing serial section sets of histological sections ( $5 \mu \mathrm{m}$ thickness). Most sections were processed for conventional hematoxylin and eosin staining; some sections were stained according to Gömori silver nitrate and counterstained with alcian-blue.

\section{Results}

The first indications of developing septal organ of the cat appear in the $6^{\text {th }}$ developmental stage by Šterrba (embryo 28 days of ontogenesis /DO/), i.e., at the end of the embryonic period. The epithelium covering the rostroventral portion of septum nasi is slightly enhanced beyond the opening of the ductus incisivus at the extended base of the nasal septum. The pseudostratified epithelium of this location reveals cell nuclei at different positions (deep, intermediate, and superficial), i.e., there are three layers of cell nuclei while the surrounding epithelial lining has only two layers. Dorsal part of septum at this level includes differential sensory epithelium of regio olfactoria. The surface of the mentioned epithelial area is not 
flat, but reveals small domes that represent smooth apical surface projections of the superficial cylindrical cells.

The septal organ is placed bilaterally on the extended base of septum nasi (Plate I, Fig. 1) in the $7^{\text {th }}$ developmental stage by Štěrba (36 DO); it is of circular shape, 62$68 \mu \mathrm{m}$ in diameter with distinct structure from surrounding epithelium (Fig. 2). Three types of cells of various shapes exist at this developmental stage, all differing in contents and distribution of the nuclear heterochromatin.

The basic part of the septal organ contents spindle cells with vertically elongated dark nuclei. These cells are concentrated at the circumference of the septal organ, surrounding the group of cells with lighter and round nuclei (Fig. 3). Some nuclei have nucleoli. The upper part of SO is formed by cone-shaped cells (Fig. 2). Their basic part is prolonged into a leg that tends to the basal membrane, the apical parts are wide and the apical surface is slightly domed and smooth. The basal membrane is less distinct in the extent of the septal organ. The entire organ is surrounded by typical cylindrical, pseudostratified, respiratory epithelium of regio respiratoria with numerous goblet cells (Fig. 2, 3). The surface of this epithelium is covered by long cilia.

In the $9^{\text {th }}$ developmental stage by Šterrba (45 DO), the islet of epithelium of septal organ is $120 \mu \mathrm{m}$ in diameter and reaches $30-40 \mu \mathrm{m}$ in thickness (Plate I, Fig. 4), whereas the surrounding epithelium of regio respiratoria is about $20 \mu \mathrm{m}$ in thickness. The epithelium of septal organ is pseudostratified, but without typical structure of epithelium in regio olfactoria. There are no goblet cells in its extent. In basal part of the SO there are vertically prolonged spindle-shaped cells. Their nuclei are hyperchromatic and prolonged in peripheral parts and become circular towards the centre of SO base (Fig. 4). The cells with round nuclei and lesser heterochromatin contents are present in the central part of SO (Fig. 4). Some nuclei are located in narrow proximity of the basal membrane, others in middle layer of epithelium and thus create two to three layers (Fig. 4). In the upper layer of epithelium, there are cone-extended cell parts creating free epithelium surface. The apical portions of these cells are slightly dome-shaped. Their surface in optical microscope is completely plain and smooth without prominences; plasma membrane is bordered with very thin dark line. This line is also visible near the surface of cone cells with cilia in regio respiratoria as well as near the surface of sustentacular cells of regio olfactoria. Round nuclei of cone cells are arranged in two layers (Fig. 5).

The basal membrane of epithelium of septal organ is not distinct, especially in central part of the islet. In the lamina propria mucosae, under the base of septal organ, there are clusters of cell nuclei and numerous cross-section of capillaries (Fig. 4). Deeply numerous blood lacunae are present and gland foundations appear solitary in the form of cellular buds. Numerous goblet cells are present in the epithelium surrounding the septal organ (Fig. 5).

\section{Discussion}

Development of the septal organ (Masera's organ) has been studied primarily in rats (Gianetti et al. 1995; Oikawa et al. 2001; Weiler and Farbman 2003). Data on the structure and development of this septal organ have not been documented in carnivores so far. First signs of epithelium differentiation of septal organ appear in cat embryos at $28 \mathrm{DO}$, which coincides with the $6^{\text {th }}$ developmental stage of Šterrba. This finding corresponds with the reports of other authors ( Gianetti et al. 1995; Oikaw a et al. 2001) who observed that septal organ appears in a rat at 15 days of ontogenesis, which is in accordance with SCS 6.

This islet of epithelium acts as a chemoreceptor that separates from the main olfactory region during development and its definitive localization is the ventral segment of septum nasi, caudally from the opening of the ductus incisivus. Its surface area in a cat under $45 \mathrm{DO}$ reaches approximately $0.045 \mathrm{~cm}^{2}$, which is consistent with that reported in literature where 
this organ presents approximately $1 \%$ of the complete area of sensory epithelium of regio olfactoria.

The range of the surface area covered by sensory epithelium of the SO, increases during ontogenesis (expanding two-fold between 36 and 45 days of ontogenesis). Initially SO cells are aggregated, forming clusters of few differentiated cells with heterochromatin-rich nuclei till the $7^{\text {th }}$ developmental stage of Štěrba. Differentiation of other cell types continues during subsequent development (over time $7^{\text {th }}$ SCS). The epithelium lacks the typical arrangement of sensory epithelium at $45 \mathrm{DO}$, but certain similarity of appearance and nuclei organization of individual cell types is supposed. Dark round nuclei occur at the base of SO epithelium, bright round nuclei in the middle level, and oval nuclei of cone cells lie in the upper part of epithelium. Moreover, there are hyperchromatic nuclei, vertically elongated or even spindle-shaped belonging to the periphery located cells. The typical placement of septal organ cells, analogous to other parts of the olfactory organ, appears after birth ( Gianetti et al. 1992, 1995; Oikawa et al. 2001). Breipohl et al. (1989), who studied septal organ development in mouse and rat by both light and electron microscopy concluded that definitive expansion as well as enhancing the number of surface structures, i.e. especially olfactory cilia, proceed during sucking period. Our observations are in accordance with these mentioned results. Apical cell surface of the upper epithelium zone is quite plain at 45 DO, but dark line near the surface cytolema presents terminal network of filaments which is necessary for forming the structures of free surface. Because sensory epithelium of regio olfactoria is characterized by numerous microvilli and olfactory cilia on the apical cell surface in the same developmental stage (45 DO), we agree with Oikaw a et al.'s (2001) opinion that SO epithelium differentiates more slowly than epithelium of the main olfactory region (MOE). Analogous to the $\mathrm{VNO}$, the SO becomes functional at the time after birth unlike olfactory epithelium, that is fully developed and dynamic before birth.

The lamina propria mucosae contains numerous capillaries under SO base in the $9^{\text {th }}$ SCS, numerous blood lacunae as well as individual non-luminated buds, i. e. bases of exocrine glands. This presence of glands associated with the $\mathrm{SO}$ was described by Katz and Merzel (1977) in the gold hamster and by Taniguchi et al. (1933) in adult rat. These glands are periodic acid - Schiff (PAS) - positive and can be dyed by alcian blue.

On the base of morphology of the sensory epithelium of the SO and the structures located in lamina propria mucosae we conclude that the SO development in the domestic cat proceeds with considerable delay compared with development of the main olfactory region.

\section{Stavba septálního Maserova orgánu kočky domácí ve vybraných stádiích ontogeneze (světelná mikroskopie)}

Septální orgán /SO/ (Masera orgán /MO/) fungující jako chemoreceptor je v současné době považován za jeden ze tří typů čichového orgánu (spolu s hlavní čichovou oblastí a vomeronasálním orgánem). Ačkoliv byl poprvé popsán již v roce 1943 Rodolfem Maserou, není zatím mnoho známo ani o vlastnostech smyslových neuronů této oblasti, ani o přesném významu tohoto orgánu v rámci chemorecepce. Existence Maserova orgánu je zatím popsána u laboratorních hlodavců a některých vačnatců. Tato práce referuje o jeho existenci u kočky domácí (Felis silvestris f. catus).

Maserův orgán se zakládá na konci embryonálního období - v 6. vývojovém stádiu dle Štěrby (u kočky 27. - 28. den ontogeneze), v souvislosti s formováním hlavní čichové oblasti dutiny nosní. Ve 45. dnu ontogeneze, tj. v 9. vývojovém stádiu dle Štěrby, má tvar kruhového až oválného ostrůvku o průměru $120 \mu$ m nacházejícího se ve ventrální části septum nasi, kaudálně od vyústění ductus incisivus. Struktura epitelu septálního orgánu je zřetelně odlišná od výstelky regio respiratoria cavi nasi. Liší se jednak celkovou výškou a uspořádáním buněk, jednak vzhledem volného povrchu a nemá v tomto období stavbu 
typického smyslového epitelu. Ani v lamina propria mucosae v rozsahu Maserova orgánu ani $\mathrm{v}$ bezprostředním okolí nejsou nejsou přítomny ani svazečky nervových vláken ani rozvinuté žlázové aciny. Žlázy jsou založeny v podobě ojedinělých neluminizovaných čepů. V okolním víceřadém epitelu se nacházejí četné buňky pohárkové.

\section{References}

BREIPOHL W, NAGURO T, WALKER DG 1989: The postnatal development of Masera's organ in the rat. Chem Senses 14: 649-662

EVANS HE, SACK WO 1973: Prenatal development of domestic and laboratory mammals. Z Vet med C, Anat Histol Embryol 2: 11-45

GIANETTI N, PELLIER V, OESTREICHER AB, ASTIC L 1995: Immunohistochemical study of the differentiation process of the septal organ of Masera in developing rats. Brain Res Dev Brain Res 84: 287-93

GIANETTI N, SAUCIER D, ASTIC L 1992: Organization of the septal organ projection to the main olfactory bulb in adult and newborn rats. J Comp Neurol 323: $288-98$

KATZ S, MERZEL J 1977: Distribution of epithelia and glands of the nasal septum mucosa in the rat. Acta Anat (Basel) 99: 58-66

OIKAWA T, SAITO H, TANIGUCHI K, TANIGUCHI K 2001: Immunohistochemical studies on the differential maturation of three types of olfactory organs in the rats. J Vet Med Sci 63: 759-65

OIKAWA T, SUZUKI K, SAITO TR, TAKAHASHI KW, TANIGUCHI K 1998: Fine structure of three types of olfactory organs in Xenopus leavis. Anat Rec 252: 301-10

RODOLFO-MASERA T 1943: Su lesistenza di un particolare organo olfactivo nel setto nasale della cavia e di altri roditori. Arch Ital Anat Embryol 48: 157-212

ŠTĚRBA O 1995: Staging and ageing of mammalian embryos and fetuses. Acta Vet Brno 64: 83-89

TANIGUCHI K, ARAI T, OGAWA K 1993: Fine structure of the septal olfactory organ of Masera and its associated gland in the golden hamster. J Vet Med Sci 55: 107-16

WEILER E, FARBMAN AI 2003: The septal organ of the rat during postnatal development. Chem Senses 28 : 581-93 
Plate I

Kociánová I. et al.: Light Microscopy ... pp. 471-475
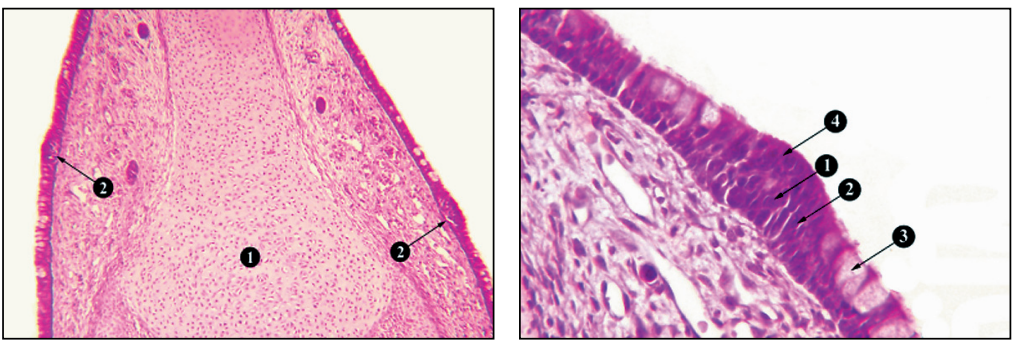

Fig. 1. Foetus, 36 DO (SCS 7), cat. Fig. 2. Foetus, 36 DO (SCS 7), cat. Septal Localization of septal organ of Masera on septum nasi, cross section, $\mathrm{HE}, \times 100$ 1) septum nasi, 2) septal organ of Masera organ of Masera, cross section, $\mathrm{HE}, \times 400$ 1) lightly staining nucleus of differentiating neurosensory cell, 2) darkly staining nucleus of sustentacular cell, 3) goblet cell, 4) coneshaped cell
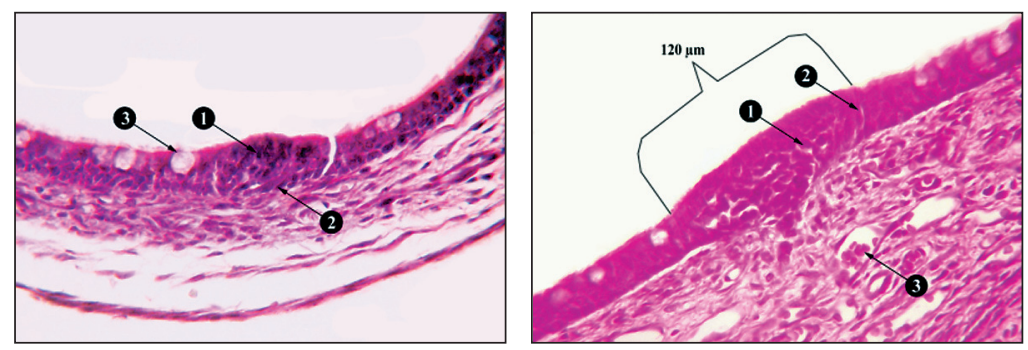

Fig. 3. Foetus, 36 DO (SCS 7), cat. Section of Fig. 4. Foetus, 45 DO (SCS 9), cat. Septal marginal part of septal organ, cross section, $\mathrm{HE}, \times 400$

organ of Masera, cross section, HE, $\times 400$

1) differentiating sense cell, 2) sustentacular 1) elongated dark nucleus of sustentacular cell, 3) capillary

cell, 2) dark round nucleus of basal cell,

3) goblet cell

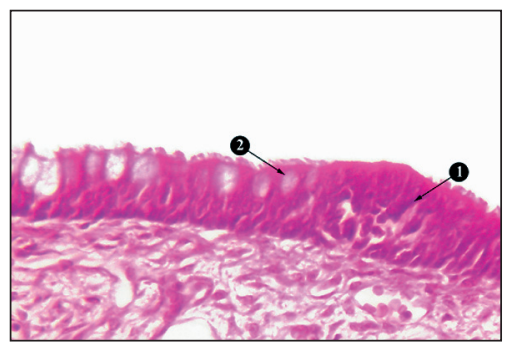

Fig. 5. Foetus, 45 DO (SCS 9), cat. Section of marginal part of septal organ of Masera, HE, $\times 400$

1) sustentacular cell, 2) goblet cell in surrounding pseudostratified columnar epithelium 